\title{
Bacterial nanocellulose and fibroin: natural products to produce a structure membranes
}

\author{
Nanocelulose bacteriana e fibroína: \\ produtos naturais para a produção \\ de membranas estruturais
}

\author{
Victória Soares Soeiro ${ }^{1}$, Louise Lacalendola Tundisi ${ }^{2}$, Venâncio Alves Amaral ${ }^{3}$, \\ Fenando Batain ${ }^{3}$, Priscila Gava Mazzola ${ }^{2}$, Elias Basile Tambourgi ${ }^{4}$, \\ José Martins de Oliveira Júnior ${ }^{5}$, Marco Vinicius Chaud ${ }^{3}$, \\ Denise Grotto ${ }^{6}$, Norberto Aranha ${ }^{1}$, Angela Faustino Jozala ${ }^{1,6}$
}

\footnotetext{
${ }^{1}$ University of Sorocaba, LAMINFE - Laboratory of Industrial Microbiology and Fermentation Process, SP-270, km 92,5, Zip Code 18023-000. Sorocaba, SP, Brazil

${ }^{2}$ University of Campinas, Faculty of Pharmaceutical Science, Rua Candido Portinari, 200, Zip Code 13083871, Campinas, SP, Brazil.

${ }^{3}$ University of Sorocaba, LABNUS - Laboratory of Biomaterials and Nanotechnology, University of Sorocaba, Av. 1777, Jardim Santa Cecilia. Zip Code 18078-005, Sorocaba, SP, Brazil

${ }^{4}$ University of Campinas, School of Chemical Engineering, Av. Albert Einstein, 500, Zip Code 13083-852, Campinas/SP, Brazil

${ }^{5}$ University of Sorocaba, LAFINAU - Laboratory of Nuclear Physics, SP-270, km 92,5, Zip Code 18023-000.

Sorocaba/SP, Brazil

${ }^{6}$ University of Sorocaba, LAPETOX - Laboratory of Toxicological Research, SP-270, km 92,5, Zip Code 18023-000,

Sorocaba/SP, Brazil

e-mail: angela.jozala@prof.uniso.br
}

\begin{abstract}
Fibroin (FB) and bacterial nanocellulose (BC) are natural products, being used in biomedicine, electronics and food industries, and other areas. All of them show biocompatibility, able to be used for many different purposes. The blending of fibroin and bacterial nanocellulose was design to produce a biocompatible material to be applied with a medical device. For this reason, the objective of this work was to evaluate the structure properties of the blending of $\mathrm{BC}$ and FB. Thus, FB was extracted from Bombyx mori and $\mathrm{BC}$ was produced by fermentation process utilizing Gluconacetobacter xylinus. The membranes composed of BC-FB were produced by immersion contact for 24 hours, at $25^{\circ} \mathrm{C}$, in $100 \mathrm{rpm}$, without crosslinking agent. After the production the membrane samples were dried and characterized by Fourier transform infrared spectroscopy (FTIR spectroscopy), mechanical proprieties, swelling efficiency, scanning electron microscopy (SEM) and computerized microtomography $(\mu \mathrm{Ct})$. Results indicate that the hydrogen-bonded porous membranes obtained displayed anisiotropic, closed and interconnected porous morphology. The morphometric characteristics, which resemble a honeycomb and consist of a long structure with high connectivity and high total porosity, amplify the areas of BC-FB blend applications, with potential utilization with optoelectronic devices, in areas ranging from environmental to tissue engineering. Furthermore, the production by immersion contact will allow the upscale process and the development of green label material.
\end{abstract}

Keywords: Polymers conjugation; Membranes; Fibroin; Bacterial nanocellulose.

\section{RESUMO}

Fibroína (FB) e nanocelulose bacteriana (BC) são produtos naturais que podem ser usados na biomedicina, nas indústrias eletrônicas e de alimentos e outras áreas. Todos eles apresentam biocompatibilidade, podendo ser utilizados para diversos fins. A mistura de fibroína e nanocelulose bacteriana foi projetada para produzir um material biocompatível para ser aplicado com um dispositivo médico. Por esse motivo, o objetivo deste trabalho foi avaliar as propriedades estruturais da mistura de BC e FB. Assim, FB foi extraída do Bombyx mori e a BC foi produzida por processo de fermentação utilizando Gluconacetobacter xylinus. As membranas compostas de BC-FB foram produzidas por contato de imersão por 24 horas, a $25^{\circ} \mathrm{C}$, em $100 \mathrm{rpm}$, sem agen- 
te reticulante. Após a produção, as amostras de membrana foram secas e caracterizadas por espectroscopia de Infravermelho com Transformada de Fourier (espectroscopia FTIR), propriedades mecânicas, eficiência de intumescimento, microscopia eletrônica de varredura (MEV) e microtomografia computadorizada $(\mu \mathrm{Ct})$. Os resultados indicam que as membranas porosas com ligações de hidrogênio obtidas apresentaram morfologia porosa anisiotrópica, fechada e interconectada. As características morfométricas, que se assemelham a um favo de mel e consistem em uma estrutura longa com alta conectividade e alta porosidade total, amplificam as áreas de aplicações da mistura BC-FB, com potencial utilização com dispositivos optoeletrônicos, em áreas que variam desde ambiental à engenharia tecidual. Além disso, a produção por contato de imersão permitirá o processo de alta qualidade e o desenvolvimento de material de rótulo verde.

Palavras-chaves: Conjugação de polímeros; Membranas, Fibroína; Nanocelulose bacteriana.

\section{INTRODUCTION}

In bioengineering, the light fibroin (FB) chain found in the silk filaments of Bombyx mori has low immunogenicity and low risk for acute cellular rejection. FB can induce cell growth based on its structure, tissue biocompatibility and non-cytotoxicity. The material size, chains with molecular weight in the range of 200-350 $\mathrm{kDa}$, does not allow the phagocytosis, and it does not cause inflammatory reactions [1-4]. Those are important characteristics in bioengineering. Nevertheless, to solubilize the FB and prevent its premature precipitation by self-assembly, the use of harsh solvents is needed. The advantage of silk fibroin is the possibility of biochemical manipulation of its solubility by artificial induction of $\beta$-sheet formation when polyaniline is incorporated [5]. The soluble FB can also be manipulated to acquire several shapes and thickness in film, fibres, nets, scaffold, mat, threads [4, 6].

Bacterial nanocellulose is a polysaccharide produced by various microorganisms including Agrobacterium, Rhizobium, Pseudomonas, Sarcina and Acetobacter. Its chemical composition is similar to vegetable cellulose, but its fibers are organized in nanometric dimensions and have unique properties such as high mechanical strength, chemical stability, hydrophilicity, crystallinity, and biocompatibility. [7-9]. Bacterial nanocellulose is a material of great industrial interest, with low cost and with a variety of application, as packing, biomedical devices [11-13]. A material composed only of fibroin does not show as good mechanical properties as one with reinforcing materials $[2,13]$. With this in mind, fibroin films with bacterial nanocellulose were developed in order to improve the mechanical properties of the material and amplify the application areas. For this reason, this study aimed to evaluate the structural properties of the blend composed for fibroin and bacterial nanocellulose by immersion contact.

\section{MATERIAL AND METHODOLOGY}

\subsection{Fibroin (FB) extraction}

Fibroin was extracted utilizing our research group protocol [14] where 5g of Bombyx mori cocoons (BratacLondrina/PR-Brazil) were used. The cocoons were cut and immersed in sodium carbonate solution (P.A., Anidrol - Diadema/SP-Brazil) prepared with MilliQ water $4.54 \mathrm{~g} / \mathrm{L}$. The solution was kept for $35 \mathrm{~min}$ at $80^{\circ} \mathrm{C}$ for sericin and other proteins withdrawal takes place since are soluble in heated sodium carbonate solution.

After the 35 minutes, the fibers were washed three times carried out for $30 \mathrm{~min}$ each with $1 \mathrm{~L}$ of purified water on a magnetic stirrer to remove the sodium carbonate. The remaining material was dried at $50^{\circ} \mathrm{C}$ for $24 \mathrm{~h}$. In order to dissolve the fibers and to form a fibroin suspension, a ternary solution containing calcium chloride (P.A., Anidrol- Diadema/SP-Brazil), ethanol (95\%, Anidrol- Diadema/SP-Brazil) and MilliQ water (1:2:8 molar ratio) was applied. The solution was then heated at $85^{\circ} \mathrm{C}$ in a water bath for $20 \mathrm{~min}$. Once the fibers reached full dissolution, the mixture was removed from the bath and cooled to room temperature $\left(23 \pm 2^{\circ} \mathrm{C}\right)$.

The fibroin suspension $(12 \mathrm{~mL})$ was placed in dialysis using a cellulose membrane with a $33 \mathrm{~mm}$ MWCO 12.000 Da (Sigma Aldrich). Each membrane containing the solution was immersed in $1 \mathrm{~L}$ of purified water under stirring for $48 \mathrm{~h}$, changing the water after $24 \mathrm{~h}$. The membranes were withdrawn and the solution was centrifuged twice at 20,000 rpm for 30 minutes to remove possible remaining impurities. The proteins concentration in fibroin solution, $\mathrm{pH} \mathrm{7,} \mathrm{was} 1 \mathrm{mg} / \mathrm{mL}$, a value similar to that reported in the literature, which is $10 \%$ [14]. To avoid contamination, the material was autoclaved at $121^{\circ} \mathrm{C}$ for $15 \mathrm{~min}$ and then stored at $8^{\circ} \mathrm{C}$.

\subsection{Bacterial nanocellulose (BC) production}

Bacterial nanocellulose (BC) was produced using Gluconacetobacter xylinus (ATCC 53582) in $20 \mathrm{~mL}$ of the 
Hestrin \& Schramm broth $(20 \mathrm{~g} / \mathrm{L}$ glucose, $5 \mathrm{~g} / \mathrm{L}$ bacteriological peptone, $5 \mathrm{~g} / \mathrm{L}$ yeast extract, $2.7 \mathrm{~g} / \mathrm{L}$ anhydrous sodium phosphate, $1.5 \mathrm{~g} / \mathrm{L}$ monohydrate citric acid) in an Erlenmeyer flask of $125 \mathrm{~mL}$. The Erlenmeyers were kept for 4 days in static culture at $30^{\circ} \mathrm{C}$, yielding $2 \mathrm{~mm}$ thick $\mathrm{BC}$. After growth, they were washed in $2 \%$ sodium dodecyl sulfate (SDS) solution in a magnetic stirrer overnight. Afterwards, they were rinsed with distilled water until SDS removal, and immersed in $1 \mathrm{M} \mathrm{NaOH}$ solution with stirring $(50 \mathrm{rpm})$ at $60^{\circ} \mathrm{C}$ for 1h30. After this period, membranes were washed again until reaching neutral $\mathrm{pH}$. They were packaged and autoclaved at $121^{\circ} \mathrm{C}$ for 15 minutes in MilliQ water, and stored at $4{ }^{\circ} \mathrm{C}[15,16]$

\subsection{Bacterial nanocellulose and fibroin membranes (BC-FB) production}

The BC-FB membranes were produced by immersion contact utilizing bacterial nanocellulose (with diameter of $150 \mathrm{~mm}$ and thickness of $2 \mathrm{~mm}$ ) with $20 \mathrm{~mL}$ of the aqueous fibroin solution $(1 \mathrm{mg} / \mathrm{mL})$ in a $125 \mathrm{~mL} \mathrm{Er}$ lenmeyer's flask at $25^{\circ} \mathrm{C}$, under agitation $(100 \mathrm{rpm}$ for $24 \mathrm{~h})$. After the immersion contact the BC-FB membranes were freeze for $24 \mathrm{~h}$ in $-80^{\circ} \mathrm{C}$ and then the membranes were lyophilized.

\subsection{Mechanical, physical-chemical and morphometric characterization}

\section{Fourier Transform Infrared Spectroscopy (ATR-FTIR)}

FTIR technique (Shimadzu, IRAffinity-1, Kyoto, Japan) was used to collect FT-IR spectra via Labs Solutions Software v.2.10. The chemical functionalities of the samples were determined by an attenuated total reflectance (ATR-8200HA) cell on the FTIR spectrophotometer over the range between 4000 and $600 \mathrm{~cm}^{-1}$, resolution of $4 \mathrm{~cm}^{-1}$, interval of $0.5 \mathrm{~cm}^{-1}$, averaging 128 scans. To evaluate the sample uniformity three samples were analysed. The membranes samples were carefully manipulated and put on the ATR support following the protocol reported by ARAUJO et al. [14].

\section{Morphometry}

The pore size, porosity (\%), and the interconnectivity of the porous in the membranes were evaluated by microtomography $(\mu \mathrm{CT})$ according to our research article [12]. The membranes pictures were captured by $\mathrm{X}$ Ray microtomography (Bruckermicro CT - SkyScan 1174, Kontich, Belgium), scanner resolution of the $28 \mathrm{mM}$ pixel, and integration time at $1.7 \mathrm{~s}$. The X-rays source was $35 \mathrm{keV}$ and $795 \mathrm{~mA}$. The projections were taken in a range of $180^{\circ}$ with an angular level of $1^{\circ}$ of circumrotating. A $3 \mathrm{D}$ virtual models, representative of various sections of scaffolds were built, and the data was mathematically managed by CT Analyzer software, v. 1.13.5.2.2.8 [15]

\section{Swelling efficiency}

The BC-FB membrane were kept at $-80^{\circ} \mathrm{C}$ in an ultra-freezer for 24 hours, lyophilized for 72 hours and the weight was assessed. The lyophilized sample was immersed in phosphate buffer solution at room temperature (25oC) for different lengthy: $0,1,2,3,4,5,6,7,8$ and 24 hours. The swelling ratio (SR) was calculated by the equation 1 [18]:

$$
\mathrm{SE} \%=\left(\llbracket \mathrm{BCFB} \rrbracket \_\mathrm{W}-\llbracket \mathrm{BCFB} \rrbracket \_\mathrm{d}\right) / \llbracket \mathrm{BCFB} \rrbracket \_\mathrm{d} \times 100
$$

in which $\mathrm{BCFB}$ and $\mathrm{BCFBd}$ are respectively the weight of the wet and dry of $\mathrm{BC}+\mathrm{BF}$ membrane.

To carry out the test, the membranes were cut to approximate in $20 \mathrm{~mm}$ of diameter, weighed and then immersed in $3 \mathrm{ml} \mathrm{PBS}$ at $37^{\circ} \mathrm{C}$ for up to 24 hours. At different times, they were removed, and two different measurements of their capacity to retain the PBS were made. The measurement was to assesses the ability of the membrane structure as a whole (the material itself together with the pore system) to absorb PBS. For this, at each time interval, the samples were removed from PBS, shaken gently, and then weighed without dripping (W). The scaffolds were then dried at $37^{\circ} \mathrm{C}$ until a constant weight was reached $(\mathrm{Wd})$. The percentage of fluid uptake, in both cases, was calculated as shown (Eq. (2)):

$$
\text { Fluid uptake of membrane }=(\mathrm{W}-\mathrm{Wd} / \mathrm{Wd}) \times 100
$$

. Each sample was measured in triplicate.

\section{Texturometer tests}

Texture profile analysis (TPA) was performed to measure the mechanical properties of sample in compres- 
sion mode for elasticity, resilience and relaxation according to ALVES et al. [17] in a Texture Analyzer (Stable Micro Systems - TA-XT Plus, Surrey, UK), with analytical Cylindric Probe P/2 and support HDP/FS-R. The travelling arm was outfitted with a load cell of $5 \mathrm{Kg}$ and the force response of the sample to the deformation imposed on it was recorded. The samples with $150 \mathrm{~mm}$ diameter were clamp in a jaw probe constrained to move in a direction perpendicular to the axis of traction without rotating. The test speed was set to a rate of $2 \mathrm{~mm} . \mathrm{s}^{-1}$ for perforation and $0.05 \mathrm{~mm} . \mathrm{s}^{-1}$ for resilience and elastic modulus. The Elastic (Young's) modulus was obtained by compressed until densification of the sample, and it was calculated with a strain that ranged between 0 and $5 \%$.

\section{Scanning Electron Microscopy morphology}

The microstructure of the materials and membranes were monitored by scanning electron microscopy (SEM) and Energy Dispersive Spectroscopy (EDS) (JEOL, Model IT200). The BC, FB and BC-FB membranes were kept at $-80^{\circ} \mathrm{C}$ in an ultra-freezer for 24 hours and lyophilized for 72 hours. The samples were previously fractured in liquid $\mathrm{N}_{2}$ and fixed to the stub with double-sided adhesive tape. Microphotographs were taken using electron beams with energy and acceleration voltage of $15 \mathrm{kV}$. The samples were randomly scanned and photomicrographed at magnifications $\mathrm{x} 5000$

\section{RESULTS AND DISCUSSION}

The BC-FB membranes were visually similar to a BC sample. The BC immersed in FB solution has slightly changed the macroscopic appearance of the samples (Figure 1).

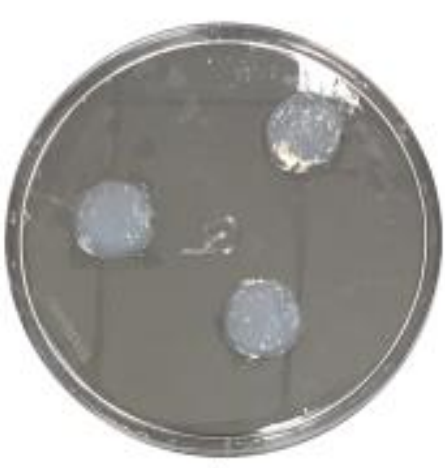

A

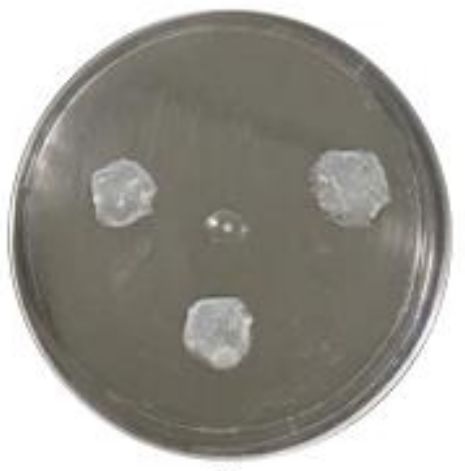

B

Figure 1: Photographs of bacterial nanocellulose (BC) membrane (A), BC-FB membrane.

The water swelling efficiency ratio (SR\%) results for BC membranes showed the water absorption capacity around $850 \%$, as shown in figure 2 . When BC was added into FB solution, the water SR\% was about $1700 \%$, doubling the swelling capacity due to the FB hydrophilic characteristics [24]. Despite that BC can naturally hold a large amount of water and the SR is an important property involved in medical applications [27-32]. 


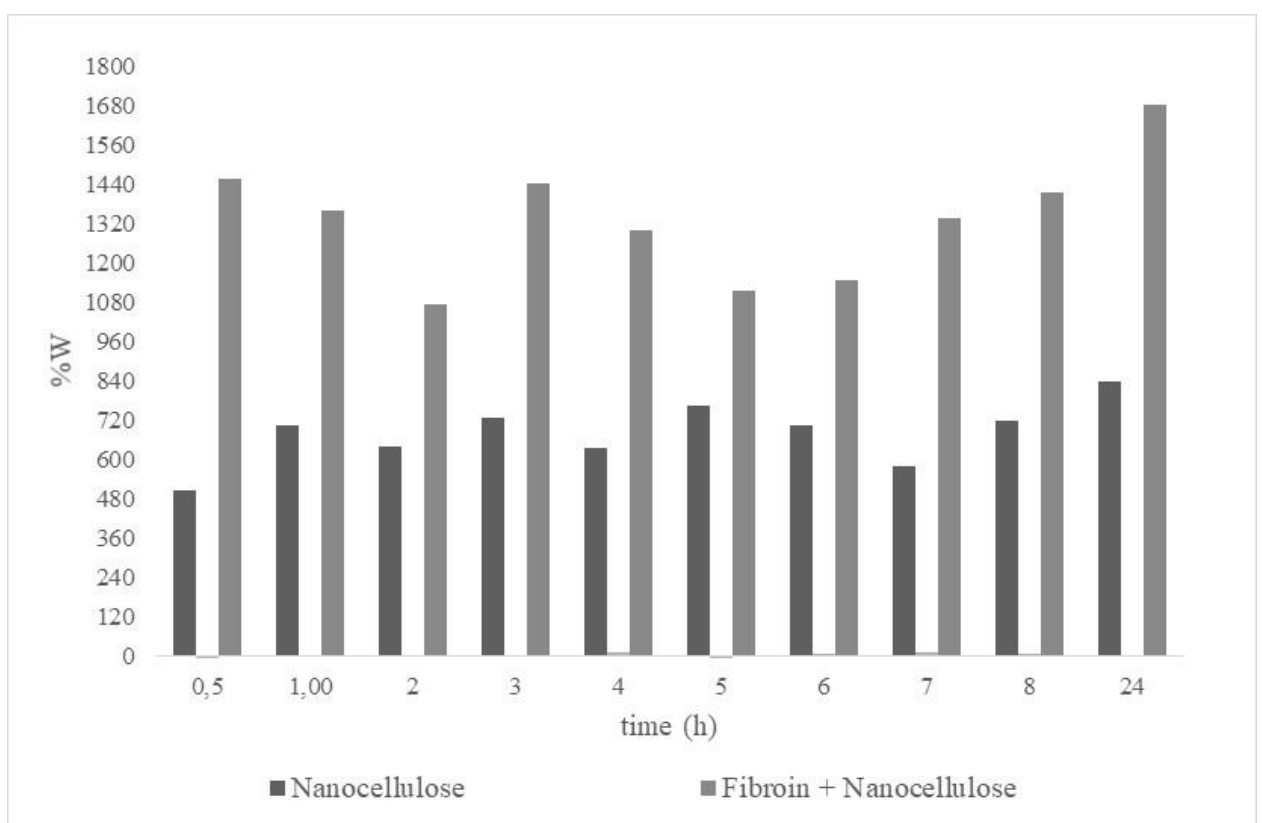

Figure 2: Swelling efficiency of BC (bacterial nanocellulose) and BC+FB (fibroin adsorbed on bacterial nanocellulose).

CHEN et al. [37] produced a material with fibroin aqueous solution (12\%(w/v) and bacterial cellulose nanoribbon (BCNR). The materials were prepared in ratios of 0:20, 1:20, 2:20, 3:20, and 4:20 via a multistaged freeze-drying method. They observed that water swelling efficiency ratio (SR\%) increased when the material reached a ratio of 2:20. The authors have concluded the material intercalated network im-proved the SR\% capacity.

MEFTAHI et al. [28] studied BC production in static culture medium and its properties after purification. BC simple dried membranes showed the water absorption capacity at around $450 \%$ after 196 hours immersion. The water absorption capacity was around two-times less than that obtained here for BC. We believe the reason for this difference in behaviour is that although the $\mathrm{BC}$ have the same production, the drying process was different.

FTIR results analyses (Figure 3) show that the chemical interaction during immersion of BC membrane into FB colloidal dispersion occur by simple $\sigma$-type polymer conjugation as there are no important band shifts after fibroin impregnation in the bacterial nanocellulose. 


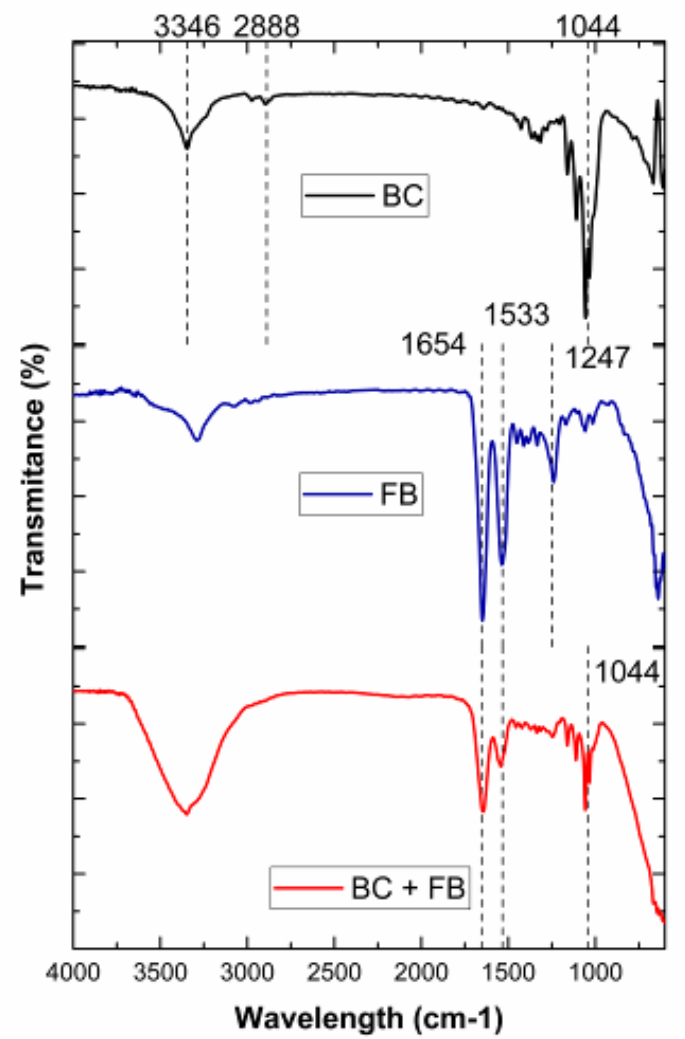

Figure 3: Fourier transform infrared spectroscopy spectra: BC (bacterial nanocellulose), FB (fibroin), BC+FB (fibroin adsorbed on bacterial nanocellulose).

The results confirm the found in FTIR spectra (Figure 3), which showed that the BC-FB interaction by hydrogen-bonded polymer conjugation. A broad band at $3500 \mathrm{~cm}^{-1}$ is associated with $\mathrm{OH}$ stretching. In addition, the positions of these bands indicate, respectively, the conformations of the protein materials (amide I, amide II, and amide III) [21, 22]. The obtained spectra of amide I $\left(1654 \mathrm{~cm}^{-1}\right)$ is related to $\alpha$-helix, $\beta$ sheets, $\beta$ turns and irregulars. Amide II spectra $\left(1533 \mathrm{~cm}^{-1}\right)$ represents the angular deformation in the plane of the N-H group $(60 \%)$ and by the $\mathrm{C}-\mathrm{N}$ stretch $(40 \%)$. The Amide III peak is a results of the combination of stretching vibrations of $\mathrm{N}-\mathrm{C}$ and flexion of group $\mathrm{C}=\mathrm{O}$, and is related to the formation of $\beta$-leaf [14, 23].

The main spectra associated with BC are $3346 \mathrm{~cm}^{-1}$ (stretch $\left.\mathrm{O}-\mathrm{H}\right) ; 2888 \mathrm{~cm}^{-1}$ (C-H stretch), $1653 \mathrm{~cm}^{-1}$ (OH-deformation) and $1044 \mathrm{~cm}^{-1}$ (CO-deformation) [19, 24-27]. However, a peak correspondent the $\beta$ glucoside linkages between the glucose units at $\sim 890 \mathrm{~cm}^{-1}$ and $\mathrm{C}-\mathrm{O}$ symmetric bridge stretching of primary alcohol $\left(1040 \mathrm{~cm}^{-1}\right)$ and $\mathrm{C}-\mathrm{O}-\mathrm{C}$ antisymmetric bridge stretching $\left(1168 \mathrm{~cm}^{-1}\right)$. The $\mathrm{C}-\mathrm{H}$ deformation for $\mathrm{CH}_{3}$ and $\mathrm{OH}$ in plane bending is observed at $1340 \mathrm{~cm}^{-1}$, and the band centred at $1400 \mathrm{~cm}^{-1}$ is related to $\mathrm{CH}_{2}$ bending and $\mathrm{OH}$ plane blending. The peak at $2888-2895 \mathrm{~cm}^{-1}$ corresponds to the $\mathrm{C}-\mathrm{H}$ stretching vibrations of aliphatic hydrocarbons. For FB was indicated by shifts of transmittance peaks characteristic vibrational bands at $1654 \mathrm{~cm}^{-1}$ (amide I: $\mathrm{C}=\mathrm{O}$ stretching), $1533 \mathrm{~cm}^{-1}$ (amide II: secondary NH bending), $1230-1270 \mathrm{~cm}^{-1}$ (amida III: $\mathrm{C}-\mathrm{N}$ stretching, and $\mathrm{C}-\mathrm{O}$ flexing).

For fibroin grafting on bacterial nanocellulose $(\mathrm{BC}+\mathrm{FB})$ by immersion method, the nanocellulose bands in the region $1000-1300 \mathrm{~cm}^{-1}$ are observed at the same positions although less relative intensities than $\mathrm{BC}$ spectra. It is possible to see amide I and amide II related of fibroin but less intense than the standard. The peaks at 2888-2895 $\mathrm{cm}^{-1}$ referent at C-H stretching vibrations are absent in $\mathrm{BC}+\mathrm{FB}$.

After physico-chemical analysis, the mechanical properties for $\mathrm{BC}$ and $\mathrm{BC}-\mathrm{FB}$ membranes are explored and the results are shown in Table 1. 
Table 1: Mechanical properties for BC and BC-FB membranes

\begin{tabular}{lll}
\hline PARAMETER & BC & BC-FB \\
\hline Resilience $(\mathrm{MPa})$ & $0.71 \pm 0.16$ & $2.59 \pm 0.22$ \\
Relaxation $(\mathrm{MPa})$ & $1.49 \pm 0.05$ & $1.86 \pm 0.33$ \\
Young's modulus $(\mathrm{MPa})$ & $0.131 \pm 0.007$ & $0.113 \pm 0.006$ \\
\hline
\end{tabular}

The presence of fibroin increased the membrane capacity to absorb energy when deformed (resilience) by compression. The relaxation reflects the induced stress as functions of time for $\mathrm{BC}$ and for the $\mathrm{BC}-\mathrm{FB}$ polymeric membrane, and it helps to understand solvent transport as kinetics hydration, water permeation and pervaporation behaviours. The relaxation mechanism is essential to effective design the biomedical membrane, especially for dressing. The stress generated on BC-FB membranes was less than on BC membranes, due to stickiness of the membrane imposed by fibroin chain. For BC-FB membranes, a lower value in Young's modulus has been observed due to the presence of fibroin, that it is related with random coil conformation (Fibroin I), which derives from processing transition in the secondary structural from $\beta$-sheet to random coil molecular conformation state [31, 32].

It is possible to improve mechanical properties of fibroin as showed by LONG et al. [33] when studied silk fibroin and collagen-based membrane to repair corneal tissues and observed the improvement of optical and mechanical properties of biomaterial when fibroin was added to the samples.

WANG et al., [34] in order to prepared materials suitable for tissue engineering concluded when FB films were also prepared with polyethylene glycol, the samples presented greater flexibility compared to films composed of pure fibroin.

The mechanical properties of biomaterials are used as a guide to select its application. Highly resilient materials have high yield strength and low Young's modulus and this ability makes them ideal for bone tissue material [32, 34]. NOISHIKI et al. [35] studied films composed of FB and cellulose fibers and the results showed improved mechanical resistance. In our study, we observed the same material behaviour when FB was added to $\mathrm{BC}$ as the authors above $[19,24,32,34,35]$, which means the mechanical properties were improved.

Besides the improvement of the mechanical properties, another remarkable fact is the structure with randomly distributed pores that is formed when BC and FB are mixed (Figure 4).

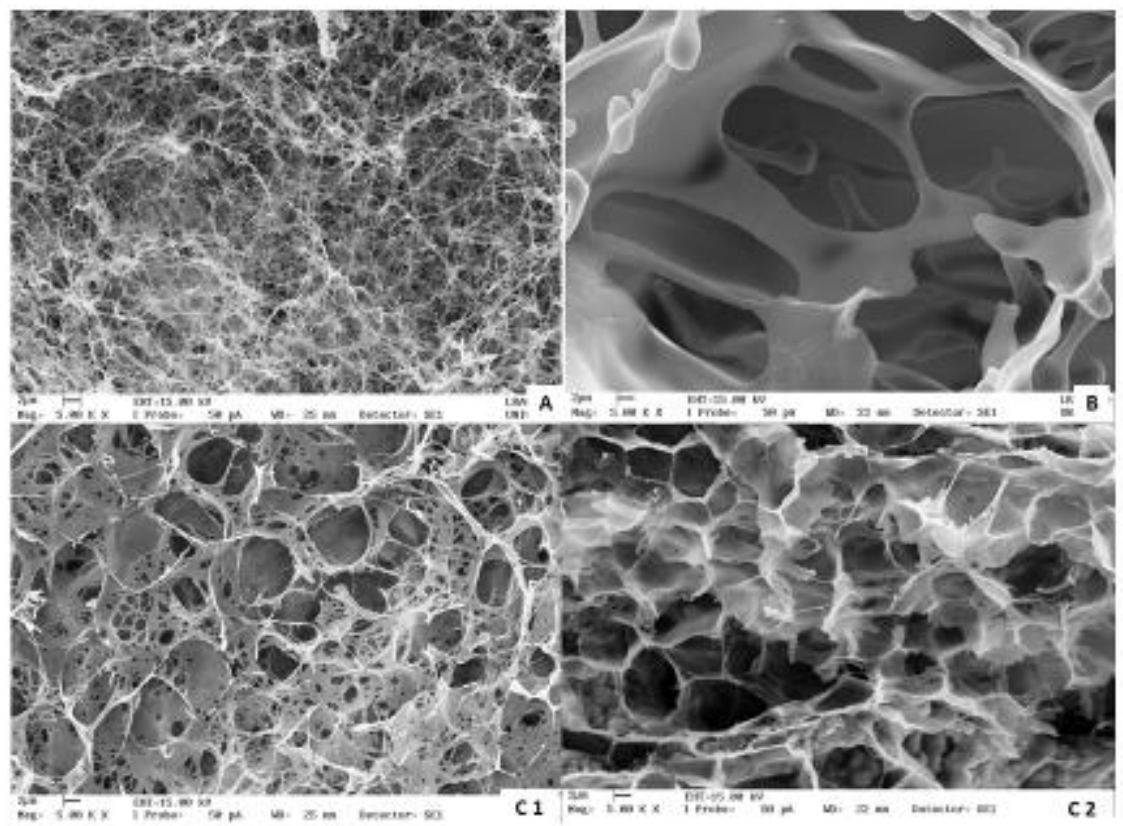

Figure 4: Scanning Electron Microscopy (SEM) microphotographs. In A, Bacterial Nanocellulose (BC); in B, Fibroin (FB) and in $\mathrm{C} 1$ and $\mathrm{C} 2$, BC-FB membranes frontal and lateral. SEM images were obtained using an accelerating voltage of $15 \mathrm{kV}$ Magnification $5.00 \mathrm{KX}$ and scale of $2 \mu \mathrm{m}$. 
The structure resembles a honeycomb, and a similar structure was observed by CHEN et al. [32]. However, the authors prepared silk FB and BC nanoribbon composite scaffolds utilizing a multi-staged freezedrying method.

Therefore, the incorporation of FB makes the membrane more anisotropic, generating a different elastoplastic behaviour and allowing the application in medical and pharmaceutical areas, tissue engineering and electronics $[37,38]$.The quantitative results of the organized structure were confirmed by X-Ray microtomography assay, presented in Table II. The pores were interconnected and distributed throughout the sample and open porosity ranged from 79.2 to $88.5 \%$, as shown in Table II. The BC structure has a lower degree of anisotropy (DA) than the BC-FB membrane. When FB was added to BC, a $49.5 \%$ increase in DA was obtained. The parameters were analysed by $3 \mathrm{D}$ virtual models, representative of various sections of scaffolds were built, and the data was mathematically managed by CT Analyzer software, v. 1.13.5.2.2.8

Table 2: X-ray microtomography parameters for samples of Bacterial nanocellulose (BC) and BC and Fibroin (BC-FB) membrane

\begin{tabular}{lll}
\hline Parameter & BC-FB & BC \\
\hline Connectivity & $58841 \pm 2942$ & $22421 \pm 1121$ \\
Degree of anisotropy & $0.794 \pm 0,04$ & $0.692 \pm 0,035$ \\
Total porosity $(\%)$ & $88.52 \pm 4.43$ & $79.15 \pm 3.96$ \\
Open porosity $(\%)$ & $88.51 \pm 4.43$ & $79.15 \pm 3.96$ \\
Volume of open pore space $(\mathrm{cm} 3)$ & $489.49 \pm 24.47$ & $237.47 \pm 11.87$ \\
\hline
\end{tabular}

*standard deviation $\mathrm{SD} \pm 5 \%$ ** data was mathematically managed by CT Analyzer software, v. 1.13.5.2.2.8

Although the BC already has a porous structure, when FB was added the volume was altered. Probably, because it was created a membrane with more elongated structed. This is can explain through the Structure Model Index (SMI), parameter indicates the presence of elongated or plate-like structures, data was mathematically managed by CT Analyzer software, v. 1.13.5.2.2.8. A plate-only structure has an SMI of 0 while if the structure is elongated, rod-like, the SMI value is 3 [35]. The BC-FB membrane showed high SMI value compared to the $\mathrm{BC}$ sample, indicating a membrane with more elongated structure. Moreover, the FB loaded in the $\mathrm{BC}$ structure showed an increase in the Fragmentation index, confirming the results of high connectivity between the structures. Connectivity is a geometric property that provides information about the structure of empty space $[38,39]$.

\section{CONCLUSION}

The results indicated the work reach the target of the developing a BC-FB membrane.. Blending of fibroin and bacterial nanocellulose led to membranes with improved mechanical and chemical properties, making them a viable option for different applications, as scaffolds, biomaterial or packaging.

The images observed showed the structure resembling a honeycomb, with a long structure, high connectivity and high total porosity. Since the structure is essential for materials, the BC-FB membrane could be exploited in other applications such as filter membranes or bone regeneration.

Additionally, the membrane production by immersion did not use hazardous substances, promoting an environmental-friendly material and reducing costs.

\section{ACKNOWLEDGMENTS}

The authors would like to acknowledge the Denicesar A. Baldo for the technical assistance for the safe operation of equipment and softwares. 


\section{BIBLIOGRAPHY}

[1] CHOUHAN, D., MANDAL, B.B. "Silk biomaterials in wound healing and skin regeneration therapeutics: From bench to bedside", Acta Biomaterialia, 2019.

[2] ALTMAN, G.H., DIAZ, F., JAKUBA, C., et al. "Silk-based biomaterials", Biomaterials, v. 24, n. 3, pp. 401-416, 2003.

[3] NGUYEN T.P., NGUYEN Q.V., NGUYEN V-H. "Silk fibroin-based biomaterials for biomedical applications: a review", Polymers (Basel), v. 11, n. 12, pp. 1933, 2019.

[4] GE, Z., YANG, Q., XIANG, X., et al. "Assessment of silk fibroin for the repair of buccal mucosa in a rat model", International journal of oral and maxillofacial surgery, v. 41, n. 5, pp. 673-680, 2012.

[5] ALVES, T.F., ARANHA, N., CHAUD, M.V. "Mechanical stress and thermal treatments induced alphahelix to beta-sheet transition in silk fibroin films", International Journal of Drug Research and Technology, v. 8, n. 3, pp. 149-157, 2018.

[6] WANG, X., YUCEL, T., LU, Q., et al. "Silk nanospheres and microspheres from silk/pva blend films for drug delivery", Biomaterials, v. 31, n. 6, pp. 1025-1035, 2010.

[7] PANESAR, P.S., CHAVAN, Y.V, BERA, M.B., et al. "Evaluation of Acetobacter strain for the production of microbial cellulose", Asian J. Chem, v. 21, n. 10, pp. 99-102, 2009.

[8] DUFRESNE, A. "Nanocellulose Processing Properties and Potential Applications", Current Forestry Reports, v. 5, pp. 76-89, 2019.

[9] JACEK, P., RYNGAJLLO, M., BIELECKI, S. "Structural changes of bacterial nanocellulose pellicles induced by genetic modification of Komagataeibacter hansenii ATCC 23769". Appl Microbiol Biotechnol, v. 103, pp. 5339-5353, 2019.

[10] BERNDT, S., WESARG, F., WIEGAND, C., et al. "Antimicrobial porous hybrids consisting of bacterial nanocellulose and silver nanoparticles", Cellulose, v. 20, n. 2, pp. 771-783, 2013.

[11] DE OLYVEIRA, G.M., COSTA, L.M.M., BASMAJI, P., et al. "Bacterial nanocellulose for medicine regenerative", Journal of Nanotechnology in Engineering and Medicine, v. 2, n. 3, p. 34001, 2011.

[12] JOZALA, A.F., DE LENCASTRE-NOVAES, L.C., LOPES, A.M., et al. "Bacterial nanocellulose production and application: a 10-year overview", Applied Microbiology and Biotechnology, v. 100, n. 5, pp. 2063-2072, 2016.

[13] AMARAL, T.S. "Nanocompósitos multifuncionas de fibroína reforçados com biocelulose", 2013.

[14] ARAÚJO, L.C.P., OLIVEIRA JÚNIOR, J.M., ARANHA, N. "Synthesis and characterization of fibroin scaffolds". Matéria (Rio de Janeiro), v. 23, n. 4, 2018.

[15] JOZALA, A.F., PÉRTILE, R.A.N., DOS SANTOS, C.A., et al. "Bacterial cellulose production by Gluconacetobacter xylinus by employing alternative culture media", Applied Microbiology and Biotechnology, v. 99, n. 3, pp. 1181-1190, 2014.

[16] ATAIDE, J.A., CARVALHO, N.M., REBELO, M.D.A., et al. "Bacterial Nanocellulose Loaded with Bromelain: Assessment of Antimicrobial, Antioxidant and Physical-Chemical Properties", DOI: 10.1038/s41598-017-18271-4.Scientific Reports, v. 7, n. 1, pp. 2-10, 2017.

[17] ALVES, T. et al. "Formulation and evaluation of thermoresponsive polymeric blend as a vaginal controlled delivery system”. Journal of Sol-Gel Science and Technology, v. 86, n. 3, p. 536-552, 2018.

[18] LIN, W-C, et al. "Bacterial cellulose and bacterial cellulose-chitosan membranes for wound dressing applications". Carbohydrate polymers, v. 94, n. 1, pp. 603-611, 2013.

[19] ALVES, T., SOUZA, J., AMARAL, V., et al.. "Biomimetic dense lamellar scaffold based on a colloidal complex of the polyaniline (PANi) and biopolymers for electroactive and physiomechanical stimulation of the myocardial", Colloids and Surfaces A: Physicochemical and Engineering Aspects, v. 579, n. July, 2019.

[20] GHOLIPOURMALEKABADI, M., SAPRU, S., SAMADIKUCHAKSARAEI, A., et al. "Silk fibroin for skin injury repair: Where do things stand?", Advanced Drug Delivery Reviews, 2019.

[21] WULANDARI, W.T., ROCHLIADI, A., ARCANA, I.M. "Nanocellulose prepared by acid hydrolysis of isolated cellulose from sugarcane bagasse", IOP Conference Series: Materials Science and Engineering, v. 107, n. 1, 2016. 
[22] MAO, K.L., FAN, Z.L., YUAN, J.D., et al. "Skin-penetrating polymeric nanoparticles incorporated in silk fibroin hydrogel for topical delivery of curcumin to improve its therapeutic effect on psoriasis mouse model", Colloids and Surfaces B: Biointerfaces, v. 160, pp. 704-714, 2017.

[23] LU, Q., WANG, X., LU, S., et al. "Nanofibrous architecture of silk fibroin scaffolds prepared with a mild self-assembly process", Biomaterials, v. 32, n. 4, pp. 1059-1067, 2011.

[24] LU, S., LI, J., ZHANG, S., et al. "The influence of the hydrophilic-lipophilic environment on the structure of silk fibroin protein", Journal of Materials Chemistry B, v. 3, n. 13, pp. 2599-2606, 2015

[25] JACEK, P., KUBIAK, K., RYNGAJŁŁO, M., et al. "Modification of bacterial nanocellulose properties through mutation of motility related genes in Komagataeibacter hansenii ATCC 53582", New Biotechnology, v. 52, n. May, pp. 60-68, 2019.

[26] MONIRI, M., MOGHADDAM, A. B., AZIZI, S., et al. "Production and status of bacterial cellulose in biomedical engineering", Nanomaterials, v. 7, n. 9, pp. 1-26, 2017.

[27] MULAKKAL, M.C., TRASK, R.S., TING, V.P., et al. "Responsive cellulose-hydrogel composite ink for 4D printing", Materials and Design, v. 160, pp. 108-118, 2018.

[28] UL-ISLAM, M., KHAN, T., PARK, J.K. "Water holding and release properties of bacterial cellulose obtained by in situ and ex situ modification", Carbohydrate Polymers, v. 88, n. 2, pp. 596-603, 2012.

[29] MEFTAHI, A., KHAJAVI, R., RASHIDI, A., et al. "Effect of Purification on Nano Microbial Cellulose Pellicle Properties", Procedia Materials Science, v. 11, pp. 206-211, 2015.

[30] OLIVEIRA BARUD, H.G., BARUD, H.D.S., CAVICCHIOLI, M., et al. "Preparation and characterization of a bacterial cellulose/silk fibroin sponge scaffold for tissue regeneration", Carbohydrate Polymers, v. 128, pp. 41-51, 2015.

[31] WANG, K., MA, Q., ZHANG, Y.M., et al. "Preparation of bacterial cellulose/silk fibroin doublenetwork hydrogel with high mechanical strength and biocompatibility for artificial cartilage", Cellulose, v. 27, n. 4, pp. 1845-1852, 2019.

[32] QI, Y., WANG, H., WEI, K., et al. "A review of structure construction of silk fibroin biomaterials from single structures to multi-level structures", International Journal of Molecular Sciences, v. 18, n. 3, 2017.

[33] LONG, K., LIU, Y., LI, W., et al. "Improving the mechanical properties of collagen-based membranes using silk fibroin for corneal tissue engineering", Journal of Biomedical Materials Research - Part A, v. 103, n. 3, pp. 1159-1168, 2015.

[34] WANG, Y., ZHENG, Z., CHENG, Q., et al. "Ductility and Porosity of Silk Fibroin Films by Blending with Glycerol/Polyethylene Glycol and Adjusting the Drying Temperature", ACS Biomaterials Science and Engineering, v. 6, n. 2, pp. 1176-1185, 2020.

[35] CHOCHOLATA, P., KULDA, V., BABUSKA, V. "Fabrication of scaffolds for bone-tissue regeneration", Materials, v. 12, n. 4, 2019.

[36] NOISHIKI, Y., NISHIYAMA, Y., WADA, M., et al. "Mechanical properties of silk fibroinmicrocrystalline cellulose composite films", Journal of Applied Polymer Science, v. 86, n. 13, pp. 3425-3429, 2002.

[37] CHEN, J., ZHUANG, A., SHAO, H., et al. "Robust silk fibroin/bacterial cellulose nanoribbon composite scaffolds with radial lamellae and intercalation structure for bone regeneration", Journal of Materials Chemistry B, v. 5, n. 20, pp. 3640-3650, 2017.

[38] LIEB-LAPPEN, R.M., GOLDEN, E.J., OBBARD, R.W. Metrics for interpreting the microstructure of sea ice using X-ray micro-computed tomography. Cold Regions Science and Technology, v. 138, pp. 24-35, 2017.

[39] LIM, K.S., BARIGOU, M. "X-ray micro-computed tomography of cellular food products", Food Research International, v. 37, n. 10, pp. 1001-1012, 2004.

\section{ORCID}

Victória Soares Soeiro

Louise Lacalendola Tundisi https://orcid.org/0000-0002-6890-8109

https://orcid.org/0000-0002-3374-6103 
Venâncio Alves Amaral

Fenando Batain

Priscila Gava Mazzola

Elias Basile Tambourgi

José Martins de Oliveira Júnior

Marco Vinicius Chaud

Denise Grotto

Norberto Aranha

Angela Faustino Jozala https://orcid.org/0000-0002-4617-2014

https://orcid.org/0000-0003-1822-0944

https://orcid.org/0000-0002-3795-8189

https://orcid.org/0000-0002-4734-9723

https://orcid.org/0000-0001-6435-1908

https://orcid.org/0000-0003-3618-8415

https://orcid.org/0000-0002-8782-0436

https://orcid.org/0000-0003-1954-377X

https://orcid.org/0000-0002-3763-5451 